\title{
O novo significado da "opção pelos pobres" na Teologia da Libertação*
}

Flávio Munhoz Sofiati

Introdução

Este artigo apresenta algumas considerações acerca do que significou e o que passou a significar na atualidade o termo "opção pelos pobres" no interior da tendência radical da Igreja Católica, mais precisamente no campo chamado de Cristianismo da Libertação ${ }^{1}$. Assim, o objetivo aqui é discutir a nova configuração da Teologia da Libertação (TL) a partir dos anos 2000, tendo como perspectiva teórico-metodológica as análises de Gramsci (2001) e Löwy (2000) acerca do conceito de "tendências orgânicas do catolicismo". Nesse sentido, busca-se fazer uma análise comparativa das obras de teólogos da libertação elaboradas entre os anos de 1970 e 2000, além de uma observação sistemática em trabalho de campo sobre as Pastorais da Juventude do Brasil (PJB).

Afirma-se que, com a ampliação da noção de "opção pelos pobres" para questôes ecológicas, étnicas, feministas, houve uma diluição da chave de interpretação marxista presente anteriormente, o que significa afirmar que a ideia de classe social contida nas análises dos teólogos da libertação deixa de estar presente em seus estudos mais recentes. Isso tem sido acompanhado por grande parte do Cristianismo da Libertação, mas é possível ainda identificar algumas exceçôes - entre elas a Pastoral da Juventude do Meio Popular (PJMB), que discutiu o tema em seu último congresso nacional em janeiro de
* $\mathrm{O}$ artigo retoma observaçōes expressas em comunicação apresentada no $36^{\circ}$ Encontro de Estudos Rurais e Urbanos CERU/ NAP/USP (2009); texto integral elaborado para a $33^{\text {a }}$ Reunião Anual da Anpocs (2009); livro Juventude Católica: o novo discurso da Teologia da Libertação (2012). 1. Termo formulado por Löwy (2000). 
2009, e as Comunidades Eclesiais de Base (CEBs). Todavia, o caso geral da TL é de distanciamento do método marxista de interpretação da realidade.

Como afirma Löwy (1991, pp. 103-104), não se pode deduzir que os teólogos da libertação aderiram totalmente ao marxismo. Contudo, apesar de não aceitar, por exemplo, a filosofia materialista e a ideologia ateia, a Teologia da Libertação assume a crítica marxista da Igreja Católica e das práticas religiosas que dão um caráter sagrado ao sistema de exploração capitalista. Assim, o marxismo é empregado, principalmente, na crítica às desigualdades sociais e diferenças de classe.

Como forma de comprovar essas ideias, este texto é articulado em três momentos: a discussão sobre as tendências católicas; a análise de textos dos teólogos da libertação Pablo Richard e Leonardo Boff, comparando suas atuações e obras dos anos de 1970 e seus escritos mais atuais; e a descrição da observação sistemática desenvolvida em trabalho de campo com grupos de jovens ligados à Teologia da Libertação e por meio de documentos das Pastorais da Juventude do Brasil, principalmente seu Plano Trienal.

No percurso da análise, apresentam-se alguns elementos da teoria e da prática dos cristãos da libertação que apontam para uma mudança nas suas opções preferenciais. Todavia, é necessário frisar que este artigo não pretende apresentar uma definição conclusiva do assunto, e sim contribuir para o debate em torno da temática do catolicismo contemporâneo no Brasil.

\section{Tendências católicas}

O tema das tendências orgânicas do catolicismo já foi discutido por mim em artigo anterior (cf. Sofiati, 2009). Apresento a seguir uma sistematização breve a fim de orientar o leitor naquilo que é o centro da discussão empreendida aqui, isto é, o tema das mudanças no interior do catolicismo e da Teologia da Libertação.

$\mathrm{Na}$ análise do catolicismo, a perspectiva adotada é a da existência de diferentes vertentes no interior da Igreja Católica no Brasil. Michael Löwy (2000), a partir dos estudos de Gramsci (2001), utiliza o termo "tendência" para descrever as diferenças existentes no interior da IC: tradicionalistas, modernizadores conservadores, reformistas e radicais. Ele identifica essas tendências a partir das relações sociais, principalmente as dos católicos com as várias formas de poder presentes na sociedade.

Nessa perspectiva, o conceito de "tendências orgânicas do catolicismo" é utilizado como instrumento para compreender os processos internos da 
Igreja Católica no Brasil. Essas tendências são assim definidas: 1) tradicionalistas: compostos por "um grupo muito pequeno de fundamentalistas, que defendem ideias ultrarreacionárias e às vezes até semifascistas"; 2) modernizadores conservadores: compostos por "uma poderosa corrente conservadora" extremamente "hostil à Teologia da Libertação e organicamente associada às classes dominantes"; 3 ) reformistas: compostos pelos moderados prontos "para defender os direitos humanos e apoiar certas demandas sociais dos pobres"; 4) radicais: compostos por uma "minoria pequena, mas influente" de simpatizantes da Teologia da Libertação e solidária aos movimentos sociais" (Löwy, 2000, p. 66). Löwy constrói sua definição a partir da análise de Gramsci (2001), que desenvolve uma conceituação das disputas internas na Igreja Católica italiana, caracterizadas como distintas religiôes em seu interior.

Gramsci identifica três tendências no catolicismo desde o final do século XIX: os integristas, os modernistas e os jesuítas, que, por serem uma congregação influente e coesa, são definidos também como tendência. Essas tendências representam camadas sociais do bloco católico e suas disputas podem ser consideradas similares a partidos internos que lutam pelo controle institucional do catolicismo. Os integristas, "partidários da intransigência ideológica e política”, representam o segmento conservador da sociedade. Os modernistas são uma série de "correntes bastante heterogêneas", divididas em duas forças principais: uma que se aproxima das classes populares, favorável ao socialismo, e outra que se aproxima das correntes liberais, favorável à democracia liberal (cf. Gramsci, 2001, p. 153).

Hugues Portelli, um importante estudioso da obra gramsciana, afirma que Gramsci também considera os jesuítas como uma corrente de centro, localizada entre as duas tendências anteriores e que mantém o controle do Vaticano. "Gramsci considera que a principal força dos jesuítas reside no controle da sociedade civil católica e, antes de tudo, das organizaçôes de massa católica - promovidas, aliás, pelos jesuítas - e principalmente a Ação Católica e das missões" (Portelli, 1984, p. 157).

Gramsci (2001, p. 233), ao classificar a luta dessas tendências como "lutas entre partidos", considera que a unidade religiosa, principalmente dos católicos que procuram manter sua condição internacional, é aparente, pois oculta uma série de divergências em relação à visão de mundo da Igreja Católica. Portelli afirma que Gramsci caracteriza como "normal" a luta de tendências por serem "[...] a ilustração dos diferentes tipos de crise interna que toda superestrutura atravessa” (1984, p. 149). Mas Gramsci (2001) 
considera a possibilidade de transformação do conteúdo total da Igreja em determinados contextos, algo central na análise do desenvolvimento histórico do catolicismo na América Latina, pois, segundo Portelli, para Gramsci os conflitos internos entre os católicos representam a "[...] evolução estrutural e ideológica do mundo leigo, e da subordinação da Igreja a este" (1984, p. 165).

Portanto, com base no referencial de Löwy e Gramsci para análise da Igreja Católica, as tendências do catolicismo brasileiro podem ser classificadas inicialmente em: 1) tradicionalistas: compostos pelos movimentos Opus Dei, Tradição Família e Propriedade e Arautos do Evangelho; 2) modernizadores conservadores: setor no qual se insere o Movimento de Renovação Carismática Católica; 3) reformistas: entre os quais predominam as congregações que trabalham diretamente com educação, como lassalistas, salesianos e maristas; 4) radicais: compostos pelos setores ligados à Teologia da Libertação, como as CEBs, Pastorais Sociais, Pastorais da Juventude.

Essas diferenciaçôes são necessárias para compreender o local no qual se insere a Teologia da Libertação em relação ao contexto eclesiástico e social do catolicismo brasileiro. Nossa tese é que o cristianismo da libertação, em virtude das características presentes em seu processo de formação, identificadas na análise do contexto histórico da Igreja brasileira nos anos de 1980, compunha a tendência radical católica, mas, a partir dos anos de 1990, passa a se caracterizar cada vez mais como uma tendência reformista.

Nessa análise, são levados em consideração apenas uma parte dos cristãos da libertação, os jovens das pastorais da juventude e alguns escritos de Pablo Richard e Leonardo Boff. Entretanto, o recorte escolhido para a construção da argumentação possui importância significativa para a Teologia da Libertação no Brasil no contexto atual de dificuldades enfrentadas por esse segmento na Igreja e na sociedade. Não se pode desconsiderar o papel das Comunidades Eclesiais de Base no interior dessa tendência. Talvez ela seja um dos poucos setores que resiste à influência das forças conservadoras que atuam na Igreja Católica brasileira, ainda que sua capacidade de influência seja cada vez menor. Vejamos como esse processo se estabeleceu.

Em princípio, há uma reconfiguração das tendências no interior do catolicismo. Aparentemente, com a ampliação da noção de "opção pelos pobres" para questôes ecológicas, étnicas, feministas, houve uma diluição da chave de interpretação marxista, como já afirmamos. Diferentemente de diversos setores do movimento social, com a ampliação da noção de classe a partir de sua diversificação e do horizonte marxista para além de uma leitura econo- 
micista, a ideia de classe social contida nas análises dos teólogos da libertação deixou de ser visível. O significado do que ficou conhecido como "opção pelos pobres", sublinhado nas Conferências Episcopais Latino-Americanas de Medellín (1968) e Puebla (1979), sofreu alteraçôes em consequência das conclusōes das conferências de Santo Domingo (1992) e Aparecida (2007).

Para melhor compreender esse processo, os dois tópicos a seguir discutem elementos da elaboração teórica dos teólogos Richard e Boff e as práticas dos jovens ligados à Teologia da Libertação, numa perspectiva comparativa entre os enfoques adotados nos anos de 1970 e a situação atual.

\section{Elementos teóricos: os escritos de Richard e Boff}

Essas mudanças podem ser observadas, por exemplo, na análise das obras dos teólogos Pablo Richard e Leonardo Boff. Richard é considerado por Löwy (2000) um dos teólogos da libertação mais radicais nos anos de 1970. Ele participou do movimento conhecido como "Cristãos pelo Socialismo" e apoiou o governo de Salvador Allende no Chile. Organizou uma importante obra sobre a questão da idolatria na América Latina, $A$ luta dos deuses: os idolos da opressão e a busca do Deus libertador, onde afirmava, na introdução, que o principal problema não era o ateísmo, conforme professava a Santa Sé, mas a discussão acerca da "idolatria como culto aos falsos deuses do sistema de opressão" (Richard, 1982, p. 7).

Richard deixava explícita essa questão logo no título do primeiro capítulo, "Nossa luta é contra os ídolos", em que afirmava: "A luta de classes transformou-se também em uma luta do Deus de Jesus Cristo contra o Olimpo dos deuses do sistema capitalista". Nesse livro o autor defendia que o "mundo opressor é um mundo de fetiches, ídolos, sacerdotes e teólogos" (Idem, pp. 9-10), e a luta dos oprimidos passa a ser travada também no âmbito da religião. Portanto, o tema da idolatria é politizado e colocado a serviço da luta pela libertação dos empobrecidos.

Apesar das posiçôes progressistas expostas nessa obra e de sua perspectiva marxista explicitamente presente nesse período, em 2003, na Espanha, Richard publica o artigo intitulado "La iglesia y la teología de la liberación en América Latina y el Caribe: 1962-2002”, no qual faz um balanço geral da Teologia da Libertação na América Latina. Esse texto foi escrito por ocasião de um encontro latino-americano organizado por teólogos da libertação no Fórum Social Mundial que aconteceu no Brasil em 2002, na cidade de Porto Alegre (RS). 
Nesse artigo, Richard afirma que a Teologia da Libertação não quer fundar outra Igreja, mas lutar por outro modelo de instituição dentro do próprio catolicismo, isto é, no interior da Igreja Católica. Estrategicamente, não deseja a confrontação, pois sua força "reside de forma positiva em nossa capacidade de ir construindo, desde baixo e em longo prazo, um modelo de Igreja fiel ao movimento de reforma iniciado no Concílio Vaticano II e em Medellín" (Idem, p. 11).

Ele afirma também que a Teologia da Libertação tem desenvolvido uma ética e espiritualidade da vida como valor absoluto, contra os valores da pura produtividade, eficácia e ganância do sistema. Uma espiritualidade de resistência no interior do sistema atual. Dessa forma, possibilitou-se o nascimento de uma espiritualidade indígena, afrodescendente, própria da mulher, dos jovens, campesina etc. Uma espiritualidade do sujeito humano concreto que precisa de trabalho, terra, saúde, educação, participação, e que se define pela sua condição de classe, gênero, raça e cultura.

Observam-se nesse documento as mudanças de postura do militante sociorreligioso de anos anteriores, que possuía uma ação na sociedade, participando até mesmo de governos revolucionários, para uma postura de ação intraeclesial preocupada com a relação do cristianismo da libertação com a instituição católica e sua posição no interior da mesma. Ao falar de uma teologia plural, recorre a uma perspectiva espiritualista de ação, preocupada com a manutenção e conservação da Teologia da Libertação no catolicismo latino-americano. Diante de um cenário desfavorável para um tipo de espiritualidade militante, com opções radicais e com perfil de trabalho com os empobrecidos, enfatiza-se a opção pelo diálogo com a instituição em busca de garimpar espaços em sua estrutura.

A radicalização dessa postura vem com um texto publicado em 2007 "Aparecida: una versión breve y crítica del documento conclusivo" -, que analisa o documento final da V Conferência Geral do Episcopado Latino-Americano de Aparecida. O documento tem a seguinte conclusão:

Como dijimos al inicio de nuestra presentación, la evaluación del evento mismo en Aparecida y del documento conclusivo final es muy positiva y debe llenarnos de esperanza y entusiasmo. Se hizo visible en la Iglesia latinoamericana y caribeña la acción del Espiritu Santo en la conducción de la asamblea y en la composición del Documento Final. Aparecida no fue únicamente un documento, sino un evento donde la Iglesia reencontró y reconstruyó su identidad forjada en el Concilio Vaticano II, Medellín y Puebla. Fue un momento de oración y de celebración (Richard, 2007, p. 17). 
Richard considera positivas as conclusōes de um documento escrito sem a participação dos setores ligados ao cristianismo da libertação - é importante lembrar que eles organizaram uma atividade paralela em Aparecida e tiveram acesso restrito ao evento - e que antes de ser publicado passou pelo crivo da Santa Sé. Ou seja, trata-se de um texto que fortalece a linha conservadora assumida por João Paulo II e ratificada por Bento XVI em seu pontificado.

Além disso, esse documento foi amplamente assumido pelos setores conservadores do catolicismo brasileiro. Por exemplo, Moysés Louro de Azevedo, fundador e principal liderança da Comunidade Católica Carismática Shalom, afirma que:

O documento de Aparecida [V Conferência do CELAM/Brasil 2007] é a nossa cara, somos nós lá. É a Igreja confirmando o derramamento de graças, dizendo: "É a vez de vocês! Vão, assumam! Levem à frente!" [...] Infelizmente, tenho que dizer, determinadas linhas da Teologia da Libertação não deixaram de ser um moralismo social [...] é por isso que o Espírito nos foi treinado na Renovação Carismática para ser a resposta certa... (Carranza et al., 2009, p. 9, transcrição de trecho do CD "A vida comunitária como sustento do profetismo", Congresso, Fraternidade).

O movimento carismático, considerado uma tendência católica modernizadora conservadora, é o setor que aproveitou com sucesso os pontificados de João Paulo II e Bento XVI. No Brasil, ele tem crescido de forma acelerada na última década por meio de uma estratégia agressiva de ação nos meios de comunicação, principalmente na TV e no rádio. Além disso, suas comunidades de vida e aliança tornaram-se alicerces e centro de difusão de uma visão religiosa frontalmente oposta aos preceitos do cristianismo da libertação.

A Renovação Carismática articulou grande parte da agenda de Bento XVI em sua visita ao Brasil em 2007, que reacendeu o debate e a crítica acerca das posiçóes conservadoras da Igreja Católica. Seu discurso contra a legalização do aborto e a defesa de temas tradicionalistas, como o retorno da missa em latim, expressaram objetivamente as posiçôes de Roma. Além disso, a presença de Bento XVI teve o sentido de fortalecer a estratégia católica de recuperação de fiéis na América Latina. Dessa forma, demonstrou-se uma simpatia do papa aos movimentos católicos com certo sucesso nessa estratégia, em particular a Renovação Carismática Católica.

Reconhecendo que a conjuntura eclesial para o próximo período deverá ampliar as dificuldades de existência da Teologia da Libertação e o conjunto de pastorais e movimentos que compóem o que chamamos de 
cristianismo da libertação, Pablo Richard assume uma postura de diálogo com a instituição no intuito de construir um cenário mais favorável para a sobrevivência da tendência. Entretanto, na medida em que busca se adequar à situação de conservadorismo do catolicismo contemporâneo, expressada principalmente pelas posiçôes de Roma e do alto escalão do episcopado latino-americano, ele acaba por transformar as próprias perspectivas da proposta de libertação de seu movimento socioeclesial, que, se no passado teve uma tônica voltada para o social, na atualidade tem se fortificado em sua vertente eclesial em virtude da priorização da ação no interior da Igreja como estratégia de sobrevivência.

Para aprofundar os argumentos deste artigo, faremos a seguir a comparação de alguns dos textos de Leonardo Boff dos anos de 1970 com sua recente obra sobre a questão ecológica, mostrando como ela expressa de forma cristalina o novo significado da "opção pelos pobres" na Teologia da Libertação. Por exemplo, em seu livro Jesus Cristo libertador, dos anos de 1980, a noção de "pobre" estava profundamente influenciada pela concepção marxista de classe social. Já no livro Saber cuidar, escrito nos anos de 1990, houve um distanciamento da noção de classe, uma vez que Boff analisa a questão ecológica sem focar a destruição do meio ambiente provocada pelo sistema de produção capitalista.

Isso significa que a Teologia da Libertação, no momento em que busca ampliar essa opção com a inclusão de questôes de gênero, étnica e, principalmente, ecológica, não está propondo a diversificação da noção de excluído, mas sobretudo uma diluição da chave que explica as diferenças sociais. Portanto, ao abordar a questão ecológica em seus debates, setores ligados ao movimento passam a assumir a noção de "pobre" não mais na chave marxista de classe social, mas numa perspectiva mais próxima do significado de pobre para os setores reformistas da Igreja Católica, ou seja, não se trabalha mais "com" o pobre, mas "para" o pobre. Isso leva a uma postura assistencialista, em que a ideia de revolução/transformação/mudança não está mais no horizonte.

Um exemplo prático dessa nova realidade pode ser observado na comparação entre os parágrafos introdutórios de dois importantes livros de Boff: Jesus Cristo libertador e Civilização planetária. Vejamos:

Os anos de 1960-1970 se caracterizam pela mobilização popular e pela emergência de uma poderosa vontade de mudança social. Não bastavam as reformas. Queria-se uma libertação das opressões históricas que as grandes maiorias secularmente sofreram. Muitos cristãos, inspirados pelo Evangelho, comprometeram-se em meios pobres 
num processo de conscientização e de prática que criava os primeiros acenos de uma sociedade alternativa possível. Sobre todos os que se empenhavam por sacudir as antigas amarras, abateu-se feroz repressão por parte do Estado de Segurança Nacional e de seus aliados. A palavra libertação fora oficialmente banida dos meios de comunicação social por efeito de um decreto do ministério da justiça (Boff, 1986, p. 13).

Mais e mais se consolida o processo de globalização que se dá pela via do mercado, da política, da estratégia militar, da tecnociência, da comunicação e da espiritualidade. Junto emergem um novo tipo de consciência, o patamar planetário, uma nova lógica, a da complexidade, e uma nova cosmologia. Esta nos faz ver a Terra como parte do cosmos ainda em processo de evolução. Contemplada a partir da perspectiva dos astronautas, ela surge como um planeta azul e branco, não como uma nave inerte, mas como um imenso organismo vivo, Gaia, realidade una e diversa, contraditória e complementar, nossa pátria (pai) e mátria (mãe) comum. O ser humano se entende como filho e filha desta Terra, emergindo de forças e energias ancestrais que estão atuando no universo há bilhôes de anos (Boff, 2003, p. 7).

Ambos os parágrafos começam com uma análise da conjuntura social. No primeiro, o autor parte de uma discussão pautada em elementos sociológicos, com uma crítica da conjuntura política do período; já no segundo, a avaliação do momento é feita a partir de questões filosóficas, com resgate de elementos humanistas e de uma visão cósmica do mundo.

Assim, é evidente o referencial marxista de classe social no autor, preocupado com a condição humana e as formas de sua libertação (tema do capítulo 3 de Jesus Cristo libertador), voltado à discussão da fé, com seu centro na periferia do mundo (capítulo 1 do mesmo livro) e militante da tese da primazia do elemento antropológico sobre o eclesiológico, do social sobre o pessoal. Em Igreja: carisma e poder, o autor dedica o oitavo capítulo a discutir as características da Igreja Católica numa sociedade de classes.

Em contrapartida, vem à tona nos anos de 1990 e 2000 a ênfase da mística, do pessoal, da espiritualidade. $O$ exemplo mais recente é uma coletânea de textos intitulada Caixa Leonardo Boff, lançada recentemente e que traz comentários de Boff a partir das orações "O Senhor é meu pastor" e "Oração de São Francisco". Neles o autor centra sua discussão na questão da paz e de sentimentos presentes no mundo contemporâneo que são manejados pela fé e a força de Deus. Já em 2008, no livro Ecologia, mundialização, espiritualidade, ele defende que outra globalização será possível a partir do momento em que as pessoas derem espaço para a espiritualidade em suas vidas. 
2. Como na conferência proferida na Universidade de São Paulo em 23 de junho de 2009, em que afirma ter enviado alguns escritos de ecologia para Boff, para quem o que faltava nos escritos ecológicos de Löwy era o elemento espiritual.
Todavia, a obra mais importante dessa nova fase de Boff é o livro Saber cuidar: ética do humano-compaixão pela terra, em que utiliza a noção do "cuidar" para discutir a questão ecológica mundial. O autor afirma que o "cuidar" é mais importante do que a razão e a vontade, e que para a construção de uma nova "fase planetária da humanidade" é preciso que a ótica do cuidado esteja no cerne de uma nova ética social.

A análise contida nesse livro não é mais de ordem sociológica, mas holística. Ele tece uma crítica ao que chama de "realismo materialista" ao afirmar que essa filosofia cega o indivíduo da dimensão divina e o impossibilita de enxergar a ação de Deus no mundo. Para isso se utiliza da mitologia, da cosmologia e da física quântica, e adverte para a necessidade de surgimento de uma nova consciência como alternativa ao realismo materialista: trata-se da filosofia holística capaz de reconectar o humano com o divino.

Alguns autores, com a utilização de Weber (2005, 2002), discutem a possibilidade de um reencantamento do mundo pela religião (cf. Berger, 1973, 1985) ou pela esfera erótica (cf. Pierucci, 2003). Boff (2004) defende um reencantamento pela natureza, concebendo o planeta Terra como a mãe que gestou toda vida aqui existente. Segundo ele, é preciso recuperar o amor e a espiritualidade como caminho para a busca da essência humana e da preservação da vida.

Este artigo não visa antagonizar os escritos sobre ecologia de Boff com a visão do movimento ecossocialista, pois é evidente o diálogo intenso que mantém com autores expoentes desse movimento mundial, como por exemplo Michael Löwy. O próprio Löwy afirmou em diversas ocasióes ${ }^{2}$ que procura discutir com Boff seus escritos sobre ecologia. A questão é que Boff tem enfatizado sua análise no elemento espiritual, cósmico, humanista. Se no passado seu referencial era Marx e os marxistas, certamente hoje é Fritjof Capra, autor de $O$ tao da física e $O$ ponto de mutação. Se antes a sociologia era o alicerce para compreender a realidade, hoje o mundo é entendido a partir das descobertas da física quântica e da ressignificação que as ciências humanas deram para essa teoria.

A consequência dessa nova perspectiva teórica de Boff e de Richard é o retorno de uma ação intraeclesial que privilegia atividades no catolicismo e prioriza os temas ligados à espiritualidade. Como exemplo da nova prática concebida a partir dessa nova formulação filosófica e teológica estão as observações feitas nas Pastorais da Juventude do Brasil. Isso não significa afirmar que a teoria influenciou a prática dos cristãos da libertação, mas que houve uma relação de influência mútua entre ação e elaboração teórica, entre o 
fazer e o conceber, enfim, entre a realidade concreta e as possibilidades de interpretação dessa realidade.

\section{Elementos da prática dos cristãos da libertação: o caso da juventude}

O pressuposto aqui é que os resultados da realidade descrita acima podem ser observados, por exemplo, nos processos de mudança sofridos pelas Pastorais da Juventude do Brasil ${ }^{3}$, as quais, nos anos de 1980, tinham uma preocupação com a militância social e, nos anos 2000, passaram a concentrar seus esforços em projetos paroquiais, isto é, intraeclesiais. Com efeito, havia uma estratégia de formação e evangelização formulada pela PJB com base na ideia de "vetor", isto é, a passagem, o caminho que leva a algum lugar, a alguma situação ou, até mesmo, "o caminho a ser seguido".

Na década de 1980, а PJв fundamentava-se nesta ideia de passagem entre uma ação no interior da Igreja Católica e a sociedade civil. Havia grupos de iniciantes com atuação dentro das paróquias e grupos de militantes que atuavam em setores específicos da sociedade (escolas, meios populares, zona rural, universidades). A proposta era que os iniciantes assumissem sua militância nessas pastorais específicas para, em seguida, atuarem na sociedade civil organizada. Era esta, portanto, a diretriz que os jovens buscavam em seu processo de formação e evangelização, conforme observado no documento 44 da CNBB, que estabeleceu as linhas pastorais de atuação da PJB, e nos relatórios das Assembleias Nacionais dos anos de 1980.

A partir de 1995, esse vetor deixa de existir, não havendo mais tal diferenciação entre iniciante e militante. Na XI Assembleia Nacional da PJB, realizada em Brasília naquele ano, definiu-se a reformulação do projeto dessa pastoral em vista da sua missão evangelizadora no meio dos jovens (cf. CNBB, 1998, p. 114). A partir daí, passou a haver uma participação paritária das diversas pastorais que compunham a PJB - Pastoral da Juventude, Pastoral da Juventude Rural, Pastoral da Juventude do Meio Popular e Pastoral da Juventude Estudantil (cf. Idem, p. 118) -, ou seja, a Pastoral da Juventude (de ação nas paróquias) passou a ser uma pastoral de militantes, igual a todas as outras.

Nos anos 2000, o vetor de ação das pastorais retoma um caminho inverso, isto é, predominam açôes para reconduzir os jovens aos grupos paroquiais. Esse processo pode ser observado já na concepção do principal método de evangelização da PJB na atualidade, o Plano Trienal, cujo projeto, conhecido como Missão Jovem, fomenta a criação do dia ou da semana de evangelização na vizinhança paroquial. Assim, os jovens passam a visitar as casas, conversam
3. Compõem a PJB: Pastoral da Juventude das Comunidades(PJ) com atuação específica nas paróquias, sendo a maior entre elas; Pastoral Rural (PJR); Pastoral Estudantil (PJE) e Pastoral do Meio Popular (PJMP). 
com as pessoas, realizam orações no entorno das igrejas e, no final, convidam os cidadãos para alguma atividade na comunidade com o objetivo de conhecer o grupo de jovens e participar da dinâmica semanal da igreja.

A proposta do Plano Trienal surgiu de fato na XI Assembleia Nacional da PJB, em 1995, porém ele foi sendo aperfeiçoado e modificado até chegar neste perfil. Portanto, é o processo de articulação dos planos trienais que encerra um tipo de formação que, inicialmente, propunha uma ação da Igreja em direção à sociedade para seguir, mais tarde, um vetor inverso, qual seja, a passagem da sociedade para a ação no interior da Igreja. Nesse sentido, é importante analisar o processo de elaboração desse projeto de evangelização a partir da descrição de sua estrutura.

No geral, o Plano Trienal propõe projetos na área de ação, formação e espiritualidade. O primeiro plano durou de 1996 a 1998, o segundo, de 1999 a 2001, e o terceiro, de 2002 a 2004. A XII Assembleia Nacional da PJB (1998) avaliou e redimensionou tais projetos, e a XIII Assembleia construiu um novo Plano Trienal. Foi elaborado ainda um quarto plano, fruto da XIV Assembleia Nacional, de 2005 a 2007, que definiu linhas gerais para todas as pastorais específicas, cabendo a cada segmento desenvolver seu conteúdo em suas próprias realidades a partir dos planos trienais específicos. Por exemplo, no atual Plano Trienal (2008-2010) da PJ, que possui atuação nas paróquias, há cinco projetos: A Juventude Quer Viver; AJURI: Conhecendo a Diversidade da Juventude Indígena, Ribeirinha, Rural e Quilombola; Mística da Construção; Caminho de Esperança: Formação de Líderes e Assessores/as; Teias da Comunicação. Analisemos esses planos.

O primeiro Plano Trienal (1996-1998), que teve como base as Diretrizes Gerais da Ação Evangelizadora da Igreja no Brasil para o período de 1995 a 1999, definiu quatro projetos: (1) Missão Jovem, (2) Formação Humana - ação e formação dentro da Igreja -; (3) Cidadania - ação e formação na sociedade -; e (4) Espiritualidade. O Plano Trienal seguinte (de 1999 a 2001) visava orientar, animar e motivar as lideranças da PJB. Já se apresentava como uma referência para essas lideranças e definiu seis projetos: dois de ação (Missão Jovem; Cidadania); dois de formação (Capacitação de Coordenadores e Assessores/as para o Acompanhamento dos Grupos; Cidadania); e dois de espiritualidade (Escola de Liturgia; Escola Bíblica para Jovens).

O programa de ação, com seus dois projetos, tinha por objetivo:

Contribuir, efetivamente, na ação evangelizadora da Igreja e na construção da Nova Sociedade, dinamizando espaços de vivência que gerem sinais de vida, fortalecendo 
o protagonismo juvenil, buscando o exercício cotidiano da cidadania e revitalizando a esperança no meio da juventude (Plano Trienal 1999-2001, 1998, p. 21).

O projeto Missão Jovem buscou fortalecer o protagonismo do jovem no meio eclesial; o Cidadania tinha como pressuposto a contribuição efetiva da PJB na construção de um plano alternativo para a sociedade, em conjunto com os movimentos sociais, despertando o jovem para o exercício da cidadania. Contudo, na prática, a juventude católica estava mais envolvida nas atividades dentro da igreja.

A XIII Assembleia Nacional (2001) definiu como missão da PJB os seguintes pontos: organizar a ação pastoral com a juventude e, a partir dela, comprometer-se com Jesus Cristo e seu projeto; fortalecer a Igreja libertadora, com base na experiência do Cristo ressuscitado; possibilitar o crescimento e o aprofundamento da fé; acompanhar a elaboração do projeto de vida na perspectiva do Reino de Deus; partir da realidade do jovem; garantir espaços de vivência e partilha em pequenos grupos e/ou comunidades; reafirmar a opção profética e transformadora pelos jovens e empobrecidos; criar espaços de participação da juventude na Igreja e na sociedade, despertando a militância; contribuir para que os jovens tornem-se protagonistas da construção da Civilização do Amor (cf. Oliveira, 2002, p. 52).

Além disso, os delegados também avaliaram os dois planos anteriores, redimensionando os projetos presentes nos três programas de ação, formação e espiritualidade. O Plano Trienal 2002-2004 é fruto desse processo, podendo ser considerado mais completo e avançado em relação aos anteriores, e onde foram estabelecidas duas linhas de ação que indicam os rumos do plano:

a) Fortalecer a dimensão missionária e do anúncio das lideranças jovens junto aos outros jovens, buscando respeitar a realidade e a diversidade da juventude realizando missões jovens.

b) Incentivar, fortalecer e implementar uma formação para a cidadania que responda às necessidades concretas da vida dos jovens: escola (elaboração de currículos, gestão escolar, movimento estudantil, pré-universitários, alfabetização [...]), trabalho (luta pelo primeiro emprego, profissionalização [...]), segurança (luta contra a violência [...]), lazer, saúde (drogas, sexualidade, Aids e DSTs [...]) (Plano Trienal 2002-2004, 2001, p. 25, grifo meu).

Outra mudança no plano foi pensar os projetos a partir da realidade da pastoral, de forma que em cada programa - ação, formação, espiritualida- 
de - há projetos partilhados e projetos específicos. No plano da ação, por exemplo, o projeto Ação para a Cidadania continua sendo comum a todas as pastorais, com o objetivo de "fortalecer uma prática missionária e profética em vista da transformação da sociedade" (Idem, p. 26). Já no plano da formação, os projetos em comum são: (1) Capacitação de Coordenadores e Assessores e (2) Formação para a Vida (cidadania, cultura de paz, sexualidade, família, gênero, opção vocacional). No âmbito da espiritualidade, por sua vez, todas as pastorais compartilham os projetos (1) Formação e Vivência Bíblica e Litúrgica e (2) Expressōes e Vivência da Espiritualidade, que buscam divulgar instrumentos e práticas de espiritualidade, como por exemplo o Ofício Divino das Comunidades e a Leitura Orante da Bíblia.

A partir desse momento, o Plano Trienal representa o amadurecimento do processo de organização da PJB e seu fortalecimento diante do processo de fragmentação e pentecostalização presentes no interior da Igreja Católica. Entretanto, a temática assumida nos projetos de evangelização passa a enfatizar a questão espiritual, de formação litúrgica e bíblica dos jovens. Como o trabalho se concentrava nas atividades paroquiais, há limites de ação para pensar questôes voltadas para a realidade social, algo fortemente presente na década de 1980.

A XIV Assembleia Nacional da PJB aprovou diversas modificações no Plano Trienal, além do próprio significado da sigla: de simplesmente Pastoral passou a designar Pastorais da Juventude do Brasil. Essa assembleia também estabeleceu cinco elementos norteadores para o Plano 2005-2007:

1. Intensificar o serviço e a participação na sociedade, o diálogo com a cultura juvenil, assumindo o Anúncio do Evangelho, como testemunho de comunhão eclesial. 2. Considerar em toda Ação da PJB os âmbitos da Pessoa, Comunidade e Sociedade com enfoques interligados.

3. Ter como referência o Processo de Educação na Fé na capacitação de coordenadores e assessores.

4. Garantir a transversalidade das grandes questôes, como meio ambiente, subjetividade, gênero, etnias e paz.

5. Construir, assumindo as suas conseqências e potencialidades, a Civilização do Amor, tentativa de um Outro Mundo Possível e realizável, expressão do Reino de Deus (Plano Trienal 2005-2007, 2004, p. 8).

A partir desses elementos foram definidas sete linhas de ação: (1) intervenção na sociedade; (2) formação; (3) cultura; (4) espiritualidade; (5) 
articulação da ação pastoral; (6) comunicação; (7) sustentabilidade financeira. Na primeira, as ações estão voltadas para a defesa do jovem e adolescente na sociedade por intermédio da colaboração do participante da PJB na elaboração de políticas públicas. Quanto à formação, as preocupações são as mesmas dos planos anteriores, já que persistem as necessidades de formação integral no interior da PJB. Uma novidade é o incentivo para o jovem estruturar seu projeto de vida no sentido de alcançar seus objetivos na sociedade, sendo que a cultura passa a ser um elemento importante nesta discussão. No âmbito da espiritualidade, fortalece-se a dimensão lúdica e mantém-se a influência da Teologia da Libertação, pois a PJB busca "[p] romover uma espiritualidade encarnada [...] que possibilite a comunhão e a participação do jovem, levando-o à prática de uma ação libertadora, à vivência de uma fé pessoal e comunitária e ao testemunho de vida cristã” (Idem, p. 11). Quanto à articulação da ação pastoral, o objetivo é "[i]ntensificar a participação social e eclesial, dialogando com as organizações populares e juvenis para potencializar forças frente às temáticas relacionadas à melhoria da vida da juventude" (Idem, p. 12). Diante dessa diretriz, propôs-se um programa de comunicação e captação de recursos financeiros para viabilizar a ação pastoral. A proposta foi criar mecanismos que permitissem a autossustentabilidadeda PJB.

No triênio 2008-2010, as Pastorais da Juventude do Brasil desenvolveram seus trabalhos a partir de planos trienais específicos. Tomamos como exemplo os projetos da pastoral com atuação nas paróquias, pelo fato de ser a mais importante, possuir um maior contingente numérico e estar presente em praticamente todas as regiōes do Brasil ${ }^{4}$. O projeto A Juventude Quer Viver comporta a fiscalização e a denúncia das injustiças praticadas contra jovens em todo o país, com participação nos espaços de discussão de políticas públicas. O projeto AJURI (Mutirão) tem como proposta estudar a diversidade juvenil brasileira e fomentar sua convivência pacífica, no intuito de revitalizar a identidade cultural das etnias presentes na sociedade. $\mathrm{O}$ projeto Mística da Construção visa ao desenvolvimento da espiritualidade e ao estímulo da prática da oração. Já o projeto Caminho de Esperança procura formar lideranças para atuação no meio eclesial. Por fim, o projeto Teias da Comunicação busca resolver o problema de difusão de informações e de articulação nacional e regional presente no interior da PJB.

Entretanto, atualmente a ação das Pastorais da Juventude se desenvolve em uma nova realidade eclesial, já que a organização das pastorais nas paróquias e dioceses passou a ser questionada pela CNBB em documento
4. A PJMP tem uma atuação importante na região Nordeste, a PJR, na regiāo Sul, e a PJE possui uma presença pequena, principalmente em colégios confessionais, no Sul e Sudeste. 
produzido em 2007. Se na década de 1980 o documento 44 ("Pastoral da Juventude do Brasil") e nos anos de 1990 o documento 76 ("Marco Referencial da Pastoral da Juventude do Brasil) davam sustentação ao programa de evangelização desse setor católico, em 2007 o documento 93 ("Evangelização da Juventude: Desafios e Perspectivas Pastorais”) propôs uma reorganização dos jovens no interior da Igreja Católica.

Sugeriu-se ali que se aglutinasse em um único espaço eclesial - Setor Juventude - todas as sensibilidades e tendências dos movimentos juvenis das pastorais, o que reduziu sobremaneira a atuação das pastorais identificadas com a Teologia da Libertação, visto que se encontram ali presentes membros do movimento Carismático e dos Cursilhos de Cristandade, com características mais conservadoras. Todavia, ainda não é possível avaliar os desgastes causados por essa nova proposta de organização.

Por outro lado, os plano trienais tornaram-se a partir da década de 1990 um importante instrumento de evangelização baseada nas perspectivas sociais e religiosas da Teologia da Libertação. A necessidade de se redefinir a ação para fortalecer não só a presença da juventude no interior da Igreja, mas também sua formação pessoal e teológica, foi a tônica desses planos, que, como vimos, na prática estão direcionados para a área eclesial, mas têm projetos voltados para a inserção dos jovens na sociedade. Neste âmbito, Missão Jovem é o projeto mais relevante, pois tem como principal característica o "resgate" da juventude para o seio da comunidade católica. Nesse sentido, a PJB tornou-se mais um instrumento de recuperação de católicos, notadamente entre os jovens.

\section{Considerações finais}

Discutiu-se aqui o significado daquilo que ficou conhecido como "opção pelos pobres”, assumido nas conferências episcopais de Medellín (1968) e Puebla (1979). Essa perspectiva sofreu alterações a partir da década de 1990 em consequência das conclusões definidas nas conferências de Santo Domingo (1992) e Aparecida (2007). Com vimos, tais mudanças aparecem também na análise das obras dos teólogos Pablo Richard e Leonardo Boff. Em Jesus Cristo libertador, a noção de "pobre" estava profundamente influenciada pela concepção marxista de classe social. No entanto, em sua obra atual sobre a questão ecológica, observamos certo distanciamento da ideia de classe, na medida em que a destruição do meio ambiente não é analisada tendo como contraponto o sistema de produção capitalista. 
Ocorre, portanto, uma diluição da chave marxista de classe social, pois quando a Teologia da Libertação amplia a "opção pelos pobres" para questôes de gênero, étnica e, principalmente, ecológica, não diversifica a noção de excluído, mas, sobretudo, esmaece a explicação das diferenças sociais. Ao abordar a questão ecológica em seus debates, setores ligados à Teologia da Libertação passam a assumir a noção de "pobre" numa perspectiva mais próxima do significado de pobreza para setores reformistas da Igreja Católica.

As consequências desse processo é o retorno para uma ação intraeclesial da Teologia da Libertação, ou seja, a ação volta-se para o interior do catolicismo e assume-se uma perspectiva ligada a temas acerca da espiritualidade. Essa realidade pode ser observada, por exemplo, nos processos de mudança da PJB que, nos anos de 1980, possuía uma preocupação com a militância social e, na década seguinte, concentra seus trabalhos em projetos paroquiais.

Como conclusão, podemos elencar três tópicos mais relevantes a esse respeito: (1) nos quadros da Teologia da Libertação, sobretudo os setores ligados à ação juvenil abandonaram ou relativizaram o referencial marxista de interpretação da realidade; (2) a discussão de temas ecológicos aproximou a Teologia da Libertação de setores reformistas da Igreja; (3) houve um processo de retorno de parte desse setor para o interior da Igreja no sentido de uma ação voltada para a recuperação de fiéis. Não se podem generalizar essas conclusōes, já que o trabalho de campo se restringiu à observação dos jovens cristãos da libertação. Todavia, as contribuiçôes de Richard e Boff são significativas para esse setor católico: o primeiro faz uma excelente sistematização da história do cristianismo da libertação e esteve presente na grande maioria dos acontecimentos da Igreja Católica latino-americana; o segundo é muito lido dentro e fora do catolicismo, sendo de certa forma um porta-voz dos cristãos da libertação.

Em suma, o presente artigo trouxe elementos para o debate nas ciências sociais acerca dos fatores de mudança no catolicismo, focalizando a análise na situação da Teologia da Libertação. Assim, espera-se contribuir para compreensão da realidade atual do catolicismo brasileiro como instituição que procura formular estratégias para a disputa de fiéis num cenário contemporâneo cada vez mais plural. 


\section{Referências Bibliográficas}

BERGER, Peter L. (1973), Um rumor de anjos: a sociedade moderna e a redescoberta do sobrenatural. Petrópolis, Vozes.

(1985), O dossel sagrado: elementos para uma teoria sociológica da religião. São Paulo, Paulus.

Boff, Leonardo. (1986), Jesus Cristo libertador. Petrópolis, Vozes.

- (1994), Igreja: carisma e poder - Ensaios de eclesiologia militante. São Paulo, Ática. - (2003), Civilização planetária: desafios à sociedade e ao cristianismo. Rio de Janeiro, Sextante.

. (2004), Saber cuidar: ética do humano-compaixão pela terra. Petrópolis, Vozes.

(2008), Ecologia, mundializaçâo, espiritualidade. Rio de Janeiro, Record.

(2009), Caixa Leonardo Boff. Petrópolis, Vozes.

CARrAnZA, Brenda et al. (orgs.). (2009), Novas comunidades católicas: em busca do espaço pós-moderno. Aparecida, SP, Ideias \& Letras.

CElam. (2007), Documento de Aparecida: texto conclusivo da V Conferência do Episcopado Latino-americano e Caribe. São Paulo, Paulus.

CNBB. (1983), Pastoral da Juventude do Brasil. São Paulo, Paulus (col. Estudos, 44). (1998), Marco referencial da Pastoral da Juventude do Brasil. São Paulo, Paulus (col. Estudos, 76).

. (2006), Evangelização da juventude: desafios e perspectivas pastorais. São Paulo, Paulus (col. Estudos, 93).

Gramsci, Antonio. (2001), Cadernos do cárcere. Rio de Janeiro, Civilização Brasileira, vol. 4.

LÖwy, Michael. (1991), Marxismo e Teologia da Libertação. São Paulo, Cortez. . (2000), A guerra dos deuses: religião e politica na América Latina. Petrópolis, Vozes.

OliveIra, Rogério. (2002), Pastoral da Juventude: e a Igreja se faz jovem. São Paulo, Paulinas.

Pierucci, Antonio F. de O. (2003), O desencantamento do mundo: todos os passos do conceito em Max Weber. São Paulo, Editora 34.

Plano Trienal 1996-1998. (1995), Brasília, Setor Juventude, CNBB.

Plano Trienal 1999-2001. (1998), Brasília, Setor Juventude, CNBB.

Plano Trienal 2002-2004. (2001), Brasília, Setor Juventude, CNBB.

Plano Trienal 2005-2007. (2004), Brasília, Setor Juventude, CNBB.

Plano Trienal 2008-2010. (2007), Brasília, Setor Juventude, CNBB.

PORTelli, Hugues. (1984), Gramsci e a questão religiosa. São Paulo, Paulinas. 
Richard, Pablo et al. (1982), A luta dos Deuses: os idolos da opressão e a busca do Deus libertador. São Paulo, Paulinas.

. (2003), "La Iglesia y la Teología de la Liberación en América Latina y el Caribe: 1962-2002”. Documentos del Ocote encendido, Zaragoza, España, n. 25, febrero. . (2007), "Aparecida: Una versión breve y crítica del Documento Conclusivo". Revista Pasos, 133: 1-17, Costa Rica.

SofiAti, Flávio M. (2009), "Tendências católicas: perspectivas do cristianismo da libertação". Estudos de Sociologia, 14 (26): 121-140.

. (2011), Religião e juventude: os novos carismáticos. São Paulo, Idéias \& Letras/Fapesp. . (2012), Juventude católica: o novo discurso da Teologia da Libertação. São Carlos, SP, EDUFSCar.

Weber, Max. (2002), Ensaios de sociologia. Rio de Janeiro, LTC. . (2005), A ética protestante e o "espirito" do capitalismo. São Paulo, Cia. das Letras.

\section{Resumo}

O novo significado da "opção pelos pobres" na Teologia da Libertação

$\mathrm{O}$ artigo apresenta uma interpretação das mudanças ocorridas no interior da tendência católica ligada à Teologia da Libertação. A comparação se dá entre as décadas de 1970-1980 e de 1990-2000, as referências teóricas são Antonio Gramsci e Michael Löwy e as abordagens teológicas recaem principalmente sobre os trabalhos de Leonardo Boff e Pablo Richard. A análise baseou-se na observação de grupos das pastorais da juventude e sua produção bibliográfica voltada para a formação e a evangelização de grupos juvenis. Constataram-se não só mudanças significativas nas obras dos teólogos da libertação e nas práticas de jovens ligados às pastorais, mas também uma relação de influência mútua desses dois universos na nova prática dos setores progressistas da Igreja Católica no Brasil.

Palavras-chave: Sociologia da religião; Igreja Católica; Teologia da Libertação; Pastorais da juventude; Opção pelos pobres. 


\section{Abstract}

The new meaning of 'working for the poor' in Liberation Theology

The article presents an interpretation of the changes that have occurred within the Catholic movement linked to Liberation Theology. A comparison is made of the decades of 1970-1980 and 1990-2000, using the theories of A. Gramsci and M. Löwy, and the theological approaches found primarily in the works of L. Boff and P. Richard. Empirically the text focuses the Catholic youth pastoral groups and the literature produced for training and evangelizing young people. Significant changes can be observed in the works of liberation theologians and in the practices of young people linked to the pastoral groups with a relation of mutual influence identifiable between these two complementary universes among the new practices of the progressive sectors of the Catholic Church in Brazil.

Keywords: Sociology of religion; Catholic church; Liberation Theology; Youth pastoral groups; Working for the poor. 